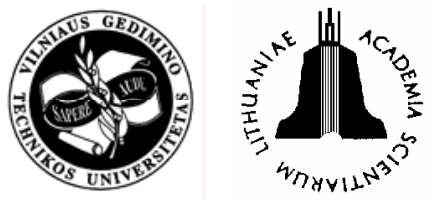

\title{
THREE PHASES OF MULTIFACTOR MODELLING OF CONSTRUCTION PROCESSES
}

\author{
Oleg Kapliński ${ }^{1}$, Leszek Janusz ${ }^{2}$ \\ ${ }^{1}$ Poznan University of Technology, 60-965 Poznan, Poland. E-mail: oleg.kaplinski@ikb.poznan.pl \\ ${ }^{2}$ ViaCon Polska, 64-130 Rydzyna, Poland. E-mail: leszek@viacon.pl \\ Received 30 Sept 2005; accepted 28 Nov 2005
}

\begin{abstract}
A multifactor modelling the construction processes is a subject of the paper. Three phases and several steps of the proposed extended procedure are presented. Tools for these phases from chronometric testing to verifying the assumed model are indicated. The following elements of the procedure as multi- and partial regression, correlation analysis, sensitivity analysis and proposed model are presented. Besides the classic verification activities the method of artificial neural networks has been applied. The processes of assembly of structural corrugated steel plate structures are a background of the consideration.
\end{abstract}

Keywords: construction management, multifactor modelling, regression analysis, sensitivity analysis, assembly of CSPS.

\section{Introduction}

Modelling and designing are some of the basic engineering activities. In case of a number of different factors influencing the process of designing and implementing a project, a multifactor modelling assistance of the process is necessary. Such modelling is part of mathematical statistics, and is primarily based on multidimensional analysis of regression and on multiple and partial correlation.

A correctly implemented procedure of such a modelling, taking into consideration additional elements (methods) may bring interesting results. There are three phases of the proposed extended procedure. The first phase involves: chronometric tests, application of induction and isomorphism methods, testing statistical hypotheses, identification of groups of factors, for example, primary and secondary. The second phase consists in finding relationships between factors using the regression and correlation, then a model of the tested process or project is built, and the degree of influence of changeability of factors on primary parameters, such as labour consumption, efficiency, or costs is identified. Therefore, we propose to introduce the so-called sensitivity analysis. The third phase consists of verification of the operation correctness of the assumed mathematical model. Besides the classic verification activities, such as checking, comparing mistakes, comparing the values of determination factors, the method of artificial neural networks can be successfully applied.

The paper presents the usage of the above-listed tools to model the processes of assembly of structural corrugated steel plate structures. These structures are very often called flexible structures. They come in useful for construction of small bridges, culverts as well as pedestrian and vehicle underpasses. Research work and analyses were focused on defining the degree of labour consumption of the assembly. The research was conducted in a number of European countries, mainly in Poland (on building sites). The paper describes designing the proposed model of identifying the degree of labour consumption. The results, presented in a graphic form, consist of a comparison of data (norms) originated from different countries. Finally, the paper signals the way in which the proposed procedure, on the basis of results derived from the model, can enrich optimisation of the process of assembly using the methodology of multicriterion optimisation. Figs 1, 2 and 3 illustrate a practical approach to multifactor modelling. The use of the mentioned three phases are described in next sections.

This paper is a synthesis of research and presentations at several conferences, including Port Elizabeth [1], Washington DC [2], Seoul [3] and in Leipzig during the $10^{\text {th }}$ Germany - Lithuania - Poland Colloquium, May 2005.

\section{Background of the considerations and applications}

Construction processes are dependant upon many factors. In order to follow the basic engineering activity as modelling, one should incorporate the influence of those factors on the model result. Only then we may consider a model to be appropriate. However, a complexity of factors can sometime create a substantial difficulty in expressing them within a model. A demand for compromise between accuracy of a model and its applicability is of paramount importance (c $\mathrm{f}$ [4]). As construction business is very much based on empirical approach, thus any new model that is created should be well supported by reliable data. An ideal situation occurs when prior to construction of a model one can obtain data through extensive research 
The first phase involves:

- chronometric tests,

- application of induction and isomorphism methods,

- $\quad$ testing statistical hypotheses

- identification of groups of factors, for example, primary and secondary ones.

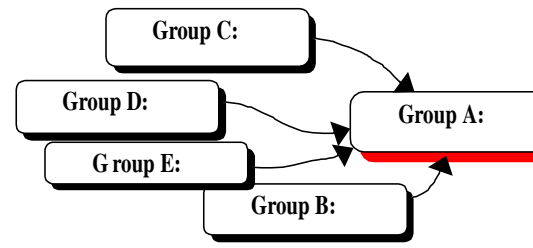

Problem position
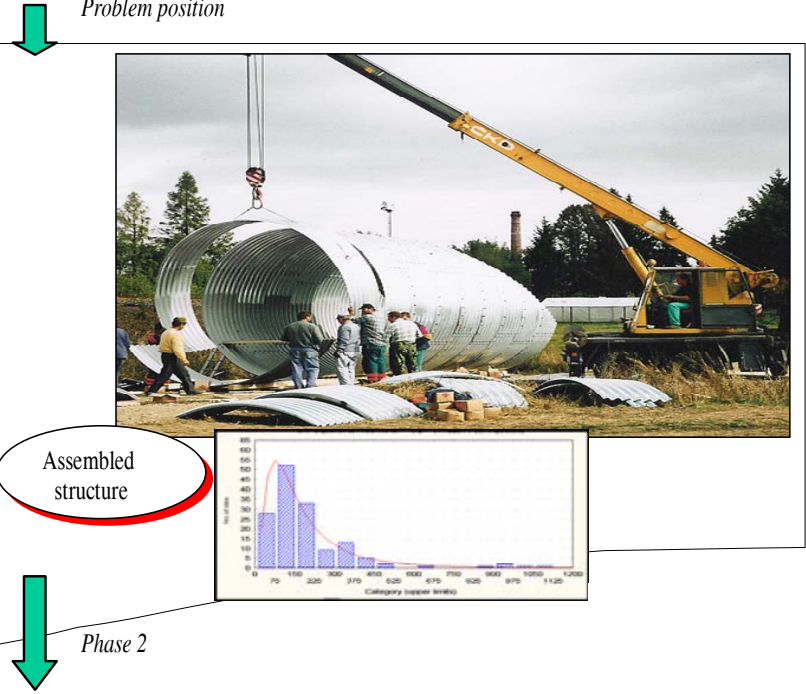

Fig 1. Scope of phase No 1

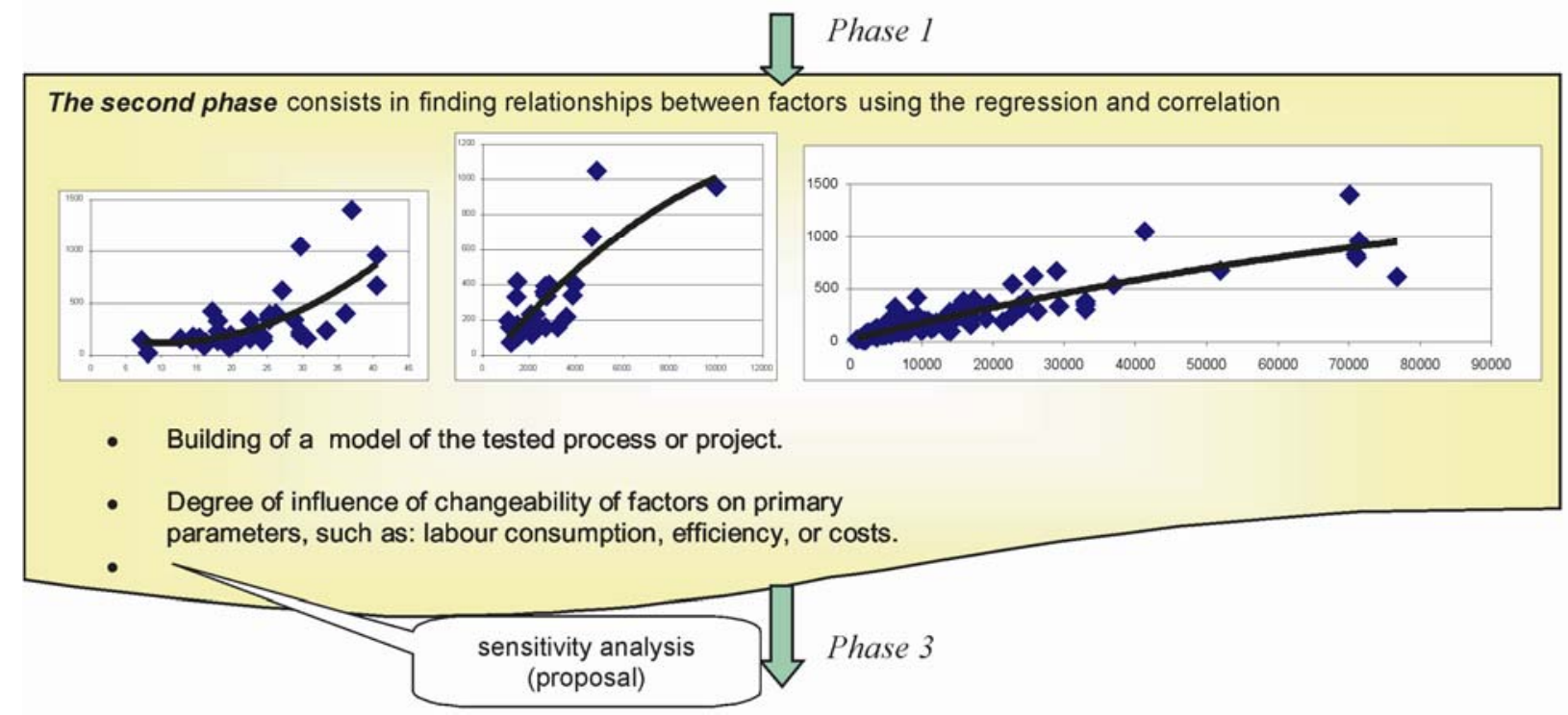

Fig 2. Scope of phase No 2

Phase 2

The third phase consists in verifying the correctness of operation of the assumed mathematical model:

- classic verification activities (checking, comparing mistakes, comparing the values of determination factors),

- $\quad$ the method of artificial neural networks

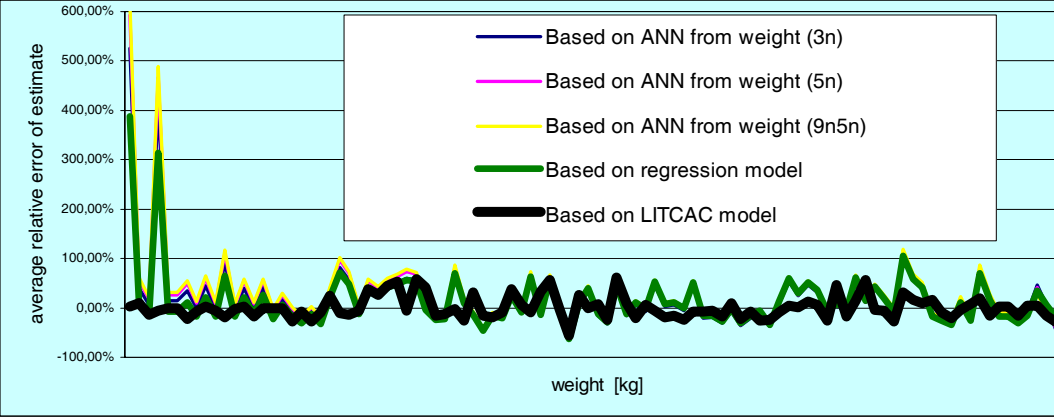

TIME OF ASSEMB LY

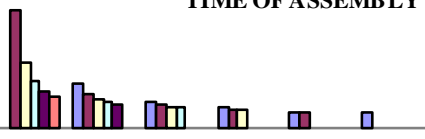

1

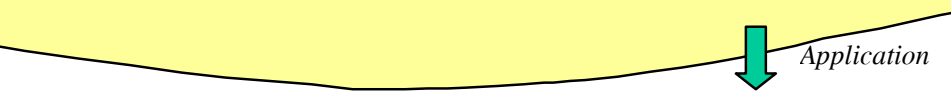

Fig 3. Scope of phase No 3 
addressing important features of modelled construction process. Assembly process of corrugated steel plate structures (CSPS) is influenced by many factors, thus can be described as multifactor process.

There are different models for the estimation of labour consumption and costs of assembly used throughout the world today. In general, they can be found in documents published by suppliers of CSPS - c f [510]. The dissertation [11] presents an attempt of the synthesis of these models. A comparison of results of labour consumption predictions with use of those models has been recently performed in Poland [11-13]. This comparison showed that those models can be described as "closed", as they will not simulate sensitivity of results based on change of specific group of factors. During 1996 to 2002 (supplemented by additional tests in the first half of 2004) field chronometric study covering 162 various cases of installation of flexible structures has been conducted [11]. This extensive research has been carried out mainly in Poland and referred mostly to 148 CSPS with corrugation of $150 * 50 \mathrm{~mm}$. Results of this research were compared with predictions obtained from identified 13 models for estimation of labour consumption from four continents (Europe, North America, Australia, Africa). It showed substantial differences in output (labour consumption). It led to the conclusion that there is a need to develop a new model for labour consumption predictions. Complete considerations of the new model and description of assembly process have been presented in [11]. This paper briefly described also the protocol of creating a multifactor model called LITCAC (Labour consumption,

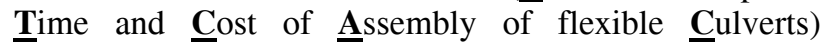
including application of regression models, sensitivity analysis, artificial neural networks (ANN, [14, 15] etc.).

Practical needs in construction industry show that the considerations in the range of cost and labour consumption are necessary. Also, the publications of Lichtarnikov $[16,17]$ can be an example supporting the reason of undertaking of the topic. However, works [16, 17] have other character - alternative designing, and other subject of research - steel structures of different nature and applications. Besides, the considerations based on multifactor modelling can offer an universal approach.

\section{Phase 1: Chronometric test and identification of factors}

The research time framework spans 1996 to 2002. The investigated jobsites were mainly in Poland but some data origin from Sweden, Ukraine and Czech Republic. The research (test) set consisted of randomly chosen installation cases satisfying statistical rules of representation for general population. Used research method was chronometric measurement of duration of identified assembly processes, i e collection of time spent on separate processes during assembly performed on job site. It was conducted under all weather conditions that occur in Central Europe. The extracted test set analyzed during development of the modelling procedure consisted of 148 cases of assembled CSPS with various shapes (5), geometry and weight. All structures that were considered during the modelling protocol had a corrugation $150 \mathrm{~mm} * 50 \mathrm{~mm}$. The test set is considered as statistically significant according to Gliwienko rule - c f [18-21].

Major elements investigated during the research consisted of:

1. labour consumption of identified assembly processes, time of assembly,

2. number of people in assembly crews,

3. tools and equipment used,

4. assembly techniques applied,

5. assembly conditions (level of difficulty, temperature, weather etc),

6. parameters and shapes of assembled CSPS,

7. experience of assembly crews,

8. other (destination of the structure-culvert, bridge, underpasss; information about location, supervision).

To support the data acquisition process many photographs were taken during assembly process in various installations and two cases have been documented also through recording on video camera. The way of reasoning was based on induction method procedure, which means that general conclusions were drawn based on a detailed analysis. This procedure is described in [4]. Results of the research were recorded on assembly cards and grouped into an aggregated data spreadsheet. Based on statistical analysis of the results, a number of key process factors and values (e g average output in identified processes, change of efficiency due to mechanization, number of tools applied etc) were obtained. Those were used later on for construction of a new model. The test set, which was called "principal", was divided into sub-sets, with the use of isomorphic rules. It allows obtaining sets with elements of identical features related to dividing criterion (similarity of shapes, similarity of assembly techniques etc). Dividing of "principal" set resulted in creation of 18 various sets of homogeneous elements. This concept is a clue for multifactor model. It creates an interface between particular factors influence on a specific case within an identified group of installation cases, and other groups of cases. This interface was possible only due to number of collected data through a detailed research and application of isomorphic rule. A schematic presentation of the division is presented in [1] and [4].

\section{Phase 2: Analysis of the research data and model}

It is possible to indicate several steps in the second phase.

Step 1: A comparison analysis

In order to evaluate the research results a comparison analysis with results obtained from identified 13 methods (models) was made. Labour consumption was compared. In order to obtain a common platform for comparison, the existing models were used as an input data recorded during collection of information performed in the research. A graph showing a comparison of the results (selected) is presented in Fig 4. 


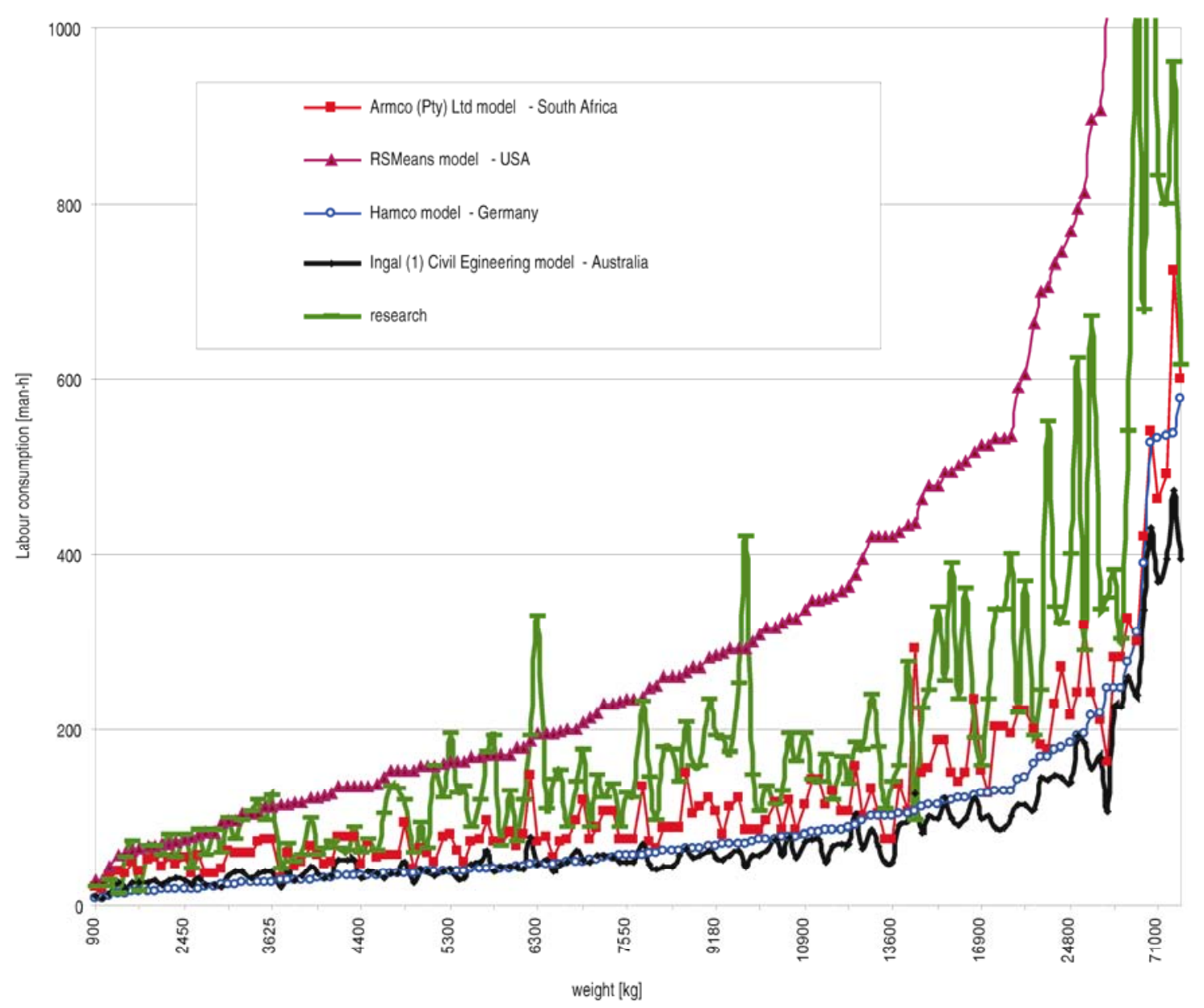

Fig 4. Comparison of results of labour consumption from existing (selected) models and research

\section{Step 2: A division of factors}

Investigation of assembly process allowed describing the sub-processes that occur during installation in a symbolic way. Recognised sub-processes are called primary processes and consist of:

1. internal transport of plates on the job site,

2. mounting of plates to shape the steel barrel,

3. bolting the plates together by means of bolts,

4. torque the bolts to required torque moment.

A division of factors affecting assembly has been proposed as follows:

1. group A: features of a structure: weight, number of plates, number of bolts, area of steel shell,

2. group B: assembly crew (number of workers, experience, motivation systems),

3. group C: used resources (electric wrenches, hand wrenches, cranes, scaffolds etc),

4. group D: assembly techniques (plate by plate, subassembly, full pre-assembly),

5. group E: external factors (weather, site conditions, other).

Factors included in groups B, C, D, E act on factors from group $\mathrm{A}$, which results in an assembled structure. Groups B, C, D contain factors and can be changed by a contractor. Factors belonging to group A are fixed for a specific case and factors belonging to group $\mathrm{E}$ are beyond the power of contractor; they are entirely independent and can not be controlled. Schematic presentation of action of factors is presented in Fig 1.

Steps 3 and 4: regression, correlation and sensitivity of results

Obtained results were recorded on assembly cards and later on grouped into aggregated data spreadsheet. Based on statistical analysis, efficiency factors for identified primary processes have been specified. These factors are additionally supplemented by indices, which represent an increase of outputs due to mechanisation of works. An identical procedure has been performed for other sub-sets mentioned earlier. In order to evaluate interdependence of factors and sensitivity of results another analyses have been performed:

1. multi- and partial regression and correlation analysis,

2. sensitivity analysis.

It was possible to state and evaluate dozens of independences of factors for assembly process of CSPS for each sub-sets. One of these cases is presented in Fig 5, which presents a model of non-linear regression for principal set (composed of 148 elements), 


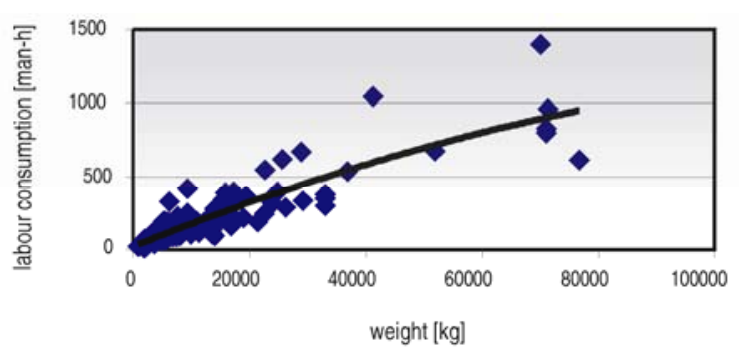

Fig 5. Model of non-linear regression for principal set (relation: labour consumption - weight)

$$
\begin{gathered}
y=-5 E-08 x^{2}+0,0161 x+22,15 \\
R^{2}=0,7928,
\end{gathered}
$$

where:

$\mathrm{x}$ - weight of structures [kg],

$\mathrm{y}$ - labour consumption [man-hours].

Aggregated results of partial regression and correlation analysis for relation: labour consumption weight of structure, for different shapes of structures, are presented in Fig 6. Based on multiple analyses of interdependence of labour and factors included in a group A, the weight of a structure was found to be the most significant for dependence of labour consumption. Full description of the results obtained from the abovementioned analysis (including dependence of labour consumption from other factors of group A) can be found in [11]. The analysis has been realised according to classical rules presented among other in [22, 23] and also in the scope of construction management [24]. A sensitivity analysis was performed on principal set, in order to evaluate the sensitivity of results on the change of various factors. The analysis was carried out for 7 different sets of factors with a help of software Statistica v.5. Results of one of them showing the sensitivity of labour consumption to change of use of mechanised wrenches (skr_zakr) and lifting equipment (sprzet) is presented in Fig 7. Conclusion from this analysis is that assembly process is sensitive to change of many factors and thus a model predicting the labour consumption must incorporate a mechanism taking this fact into account.

Step 4 (in the sphere of sensitivity analysis) is not obligatory in traditional procedure of multifactor modelling.

\section{Step 5: New model - proposal}

Based on the above-presented considerations, a new model (called LITCAC) for estimation of labour consumption has been proposed. This model is an "open" type model, which means that it allows changing of many of input parameters and permits to observe the results of the change on labour consumption. Based on it, one can estimate cost of assembly by introducing specific figures for cost items, i e labour cost, cost of machinery, overall daily cost etc. As a subsection, the model provides module for estimation of time of assembly counted in days (or shifts).

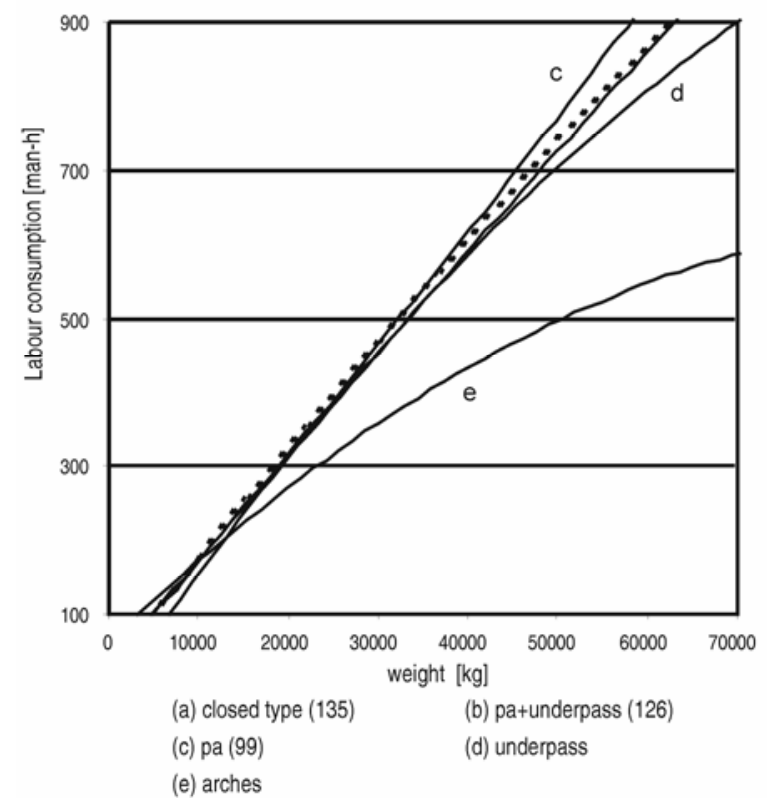

Fig 6. Aggregated regression models for dependence: labour consumption - weight (fragment)

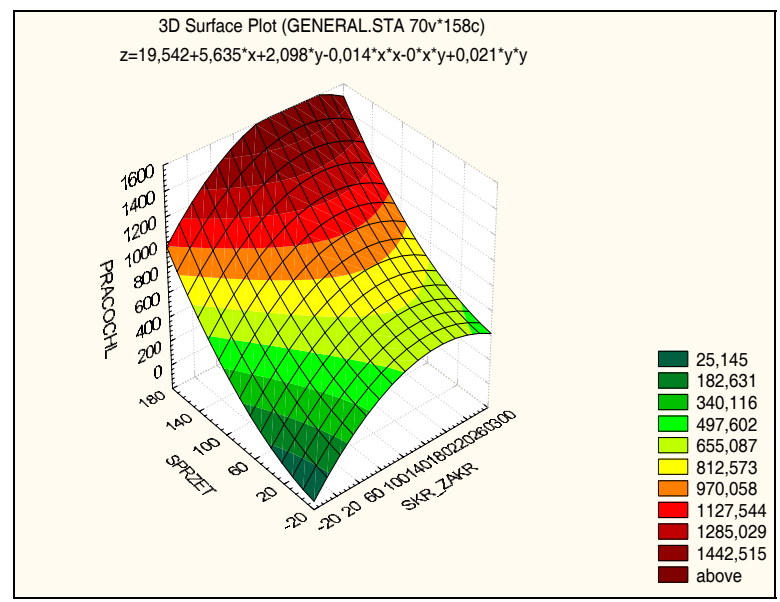

Fig 7. Sensitivity of labour consumption (Pracochl) to a change of use of lifting machines and mechanised wrenches

Mathematical notation of the model is expressed by 4 equations:

- Labour consumption of assembly,

- Time of assembly,

- Direct cost of assembly,

- Total cost of assembly including overheads and general construction daily costs.

These equations are developed and contains different coefficients and corrective indices [1, 11]. Brief description of the proposed model is presented in the Appendix. 


\section{Phase 3: Verification}

Based on regression analysis, the model provides user with information about confidentiality of prediction, i e gives estimated range of error and evaluates probability of estimation accuracy. Basically the level of accuracy ranks from: 0,79 to 0,96 , depending on test subset. It describes the average probability of estimation accuracy. On top of that, for each estimate a range of error for resulted labour consumption is generated. This distinguishes LITCAC model from other existing models, which do not provide any information about confidence level of estimations. Verification of the model has been performed based on comparison with results of regression model and simplified model, which is related to hourly output, as well as to results of analysis with the use of artificial neural networks (ANN) (based on BrainMaker Professional for Windows v.3 [25]). Additionally the model has been tested on separate cases of assembly that were not included in the test set. The verification of the model confirmed its good applicability for predictions of labour consumption (c f [3]).

The comparison of average error of estimation of labour consumption obtained from regression model, artificial neural networks and LITCAC model for subset "pa" is presented in Fig 3. The artificial neural networks have had two layers with two input parameters (weight and number of bolts) and end results, ie labour consumption.

An average relative error for the analysed test subset ("pa") obtained from LITCAC model as well as its dispersion was the lowest of compared models. The average relative error was calculated based on equation (1):

$$
\varepsilon=\left(\frac{1}{n}\right) \sum_{i=1}^{n}\left(\frac{P_{i m}(x)-P_{i b}(x)}{P_{i m}(x)}\right)
$$

where:

$\varepsilon-$ an average relative error for applied model,

$n$ - number of elements of the investigated set,

$P_{i m}(x)$ - labour consumption of assembly for specific structure based on applied model,

$P_{i b}(x)$ - labour consumption of assembly for specific structure based on research,

$x$ - weight of a structure.

The average relative error of prediction $(\varepsilon)$ for LITCAC model was $\varepsilon=0,44 \%$ with $\delta=22,40 \%$ (standard deviation), whereas ANN resulted in $\varepsilon=15,42 \%$ and $\delta=71,57 \%$ and regression model resulted in $\varepsilon=15,53 \%$ and $\delta=58,49 \%$. Comparison of the results obtained from LITCAC model with research measurements and other methods are satisfactory and show the advantage of our model.

Step-Applications

Of course, it is possible to indicate many cases of applications mentioned above three phases in practice. Fig 8 presents a simple graphical output from the LITCAC model (installation case with 5 workers equipped with different number of resources). One can notice the change of results related to resources change.
Besides, the choice of optimal assembly crews for erection of corrugated steel plate structures [6] is an interesting example of this consideration. The improvement of quality of assembly works is presented in [8].

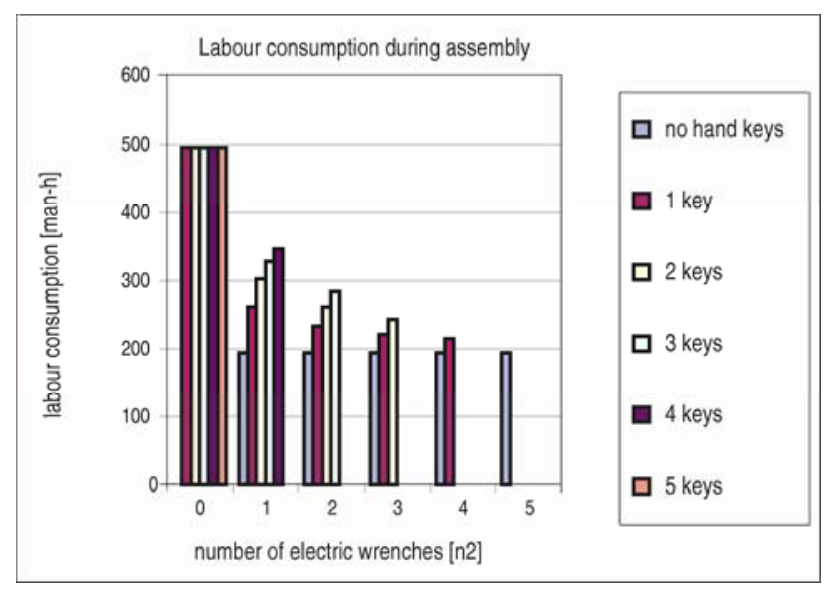

Fig 8. Result table obtained from LITCAC model

Additional step: Module of optimisation

Presented procedure of multifactor modelling can be finished at this moment. But the proposed procedure and the use of the model can be considerably enriched through the addition of the module (of the model) of the optimization. Application of multi-criteria decision making methods MCDM (for example, TOPSIS, ELECTRE or ENTROPHY, [26-29]) together with LITCAC can yield an interesting effect in optimization of the process planning. Examples of that are presented in $[1,2]$.

\section{Conclusions}

The presented procedure of multifactor modelling in construction management shows the importance of the induction method in the development of an accurate model. Moreover, this approach allows a sound verification of the model and helps users to understand the reasoning in a detailed way. The presented model incorporates an interface between technology and economy, which is well presented in reality. Utilising results from LITCAC with use of MCDM models is very useful for optimization of assembly process. The new model is constructed in its way that it can be used worldwide after minor adjustments to specific markets. There is a number of practical applications of discussed model available today. One can find some of them in [13]. This model is frequently used in Poland.

\section{Appendix}

Aggregated equations of the LITCAC model:

Labour consumption of assembly:

$$
L=\frac{W\left(n_{1}+n_{2}\right)}{\delta_{k}\left(n_{1}+n_{2} \alpha_{i}\right)+\frac{W n_{3}}{\delta_{r}\left(n_{3}+n_{4} \beta_{i}\right)}} \xi_{i}, \quad \text { [man-hours]. }
$$


Time of assembly:

$$
T=\frac{W}{\delta_{k}\left(n_{1}+n_{2} \alpha_{i}\right)+\frac{W \xi_{3}}{\delta_{r}\left(n_{3}+n_{4} \beta_{i}\right)}} \xi_{i}, \quad \text { [hours]. }
$$

Direct cost of assembly:

$$
\left.C_{\text {direct }}=W c_{1} \xi_{i}\left(\frac{n_{1}+n_{2}(1+\sigma)}{\delta_{k}\left(n_{1}+n_{2} \alpha_{i}\right)}+\xi_{3} \frac{n_{3}+n_{4} \kappa}{\delta_{r}\left(n_{3}+n_{4} \beta_{i}\right)}\right), \mathrm{USD}\right] .
$$

Total cost of assembly including overheads and general construction daily costs:

$$
\begin{aligned}
& C_{\text {total }}=W c_{1} \xi_{i}\left(\frac{n_{1}+n_{2}(1+\sigma)}{\delta_{k}\left(n_{1}+n_{2} \alpha_{i}\right)}+\xi_{3} \frac{n_{3}+n_{4} \kappa}{\delta_{r}\left(n_{3}+n_{4} \beta_{i}\right)}\right)+ \\
& +\frac{c_{0}}{r}\left(\frac{W}{\delta_{k}\left(n_{1}+n_{2} \alpha_{i}\right)}+\frac{W \xi_{3}}{\delta_{r}\left(n_{3}+n_{4} \beta_{i}\right)}\right) \xi_{i},[\mathrm{USD}] .
\end{aligned}
$$

\section{Notations}

$W$ - weight of structure,

$c_{1}-$ cost of labour,

$n_{1}-$ number of hand keys for torque of the bolts,

$n_{2}$ - number of mechanical keys for torque of the bolts,

$n_{3}-$ number of workers in an assembly crew,

$n_{4}$ - number of cranes or other lifting and transporting mechanical equipment,

$\alpha_{i}-$ an increase index due to mechanisation of bolting and torque,

$\beta_{i}-$ an increase index mechanisation of mounting steel plates,

$\delta_{k}$ - efficiency of hand torque and bolting,

$\delta_{r}$ - efficiency of on-site transportation and mounting of plates,

$\kappa-$ an index of relative cost of use of heavy equipment versus use of manpower in mounting of plates $\left(\kappa=k_{3} / \mathrm{c}_{1}\right)$, where $k_{3}$ - cost of using mechanised equipment for lifting and transporting steel plates,

$\sigma-$ an index of relative cost of use of mechanical wrenches versus use of hand-tools in torque of bolts $\left(\sigma=k_{2} / c_{1}\right)$, where $k_{2}-$ cost of using mechanised wrenches,

$\xi_{i}$ - corrective indices accounting for parallel processes occurrence,

$c_{o}$ - daily overhead costs for job side [USD/shift],

$r$-duration of a shift [ 8 hours].

\section{References}

1. Janusz, L. and Kapliński, O. Improvement of quality of assembly works of corrugated steel structures through predicting labor consumption. In: Proc of $4^{\text {th }}$ Triennial International Conference Rethinking and Revitalizing Construction Safety, Health, Environment and Quality, Port Elizabeth, South Africa, 17-20 May 2005, p. 164 174.

2. Janusz, L. and Kapliński, O. Modelling of labor consumption and cost of assembly of structural corrugated steel plate structures. In: Proc of Transportation Research Board $84^{\text {th }}$ Annual Meeting, Washington DC, Jan 9-13, 2005. 9 p.
3. Janusz, L. and Kapliński, O. Multifactor modelling in construction management. Proc of $1^{\text {st }}$ International Conference on Construction Management, Oct 16-19, 2005, Seoul, Korea. 6 p.

4. Kapliński, O. Modelling of construction processes. A managerial approach. Warsaw: IPPT PAN, 1997. 175 p.

5. Catalogue: Armco: Construction Products. CSP Newport, Armco, South Africa, 1985. 85 p.

6. Catalogue: Ingal Civil Products: Buried corrugated metal structures. Industrial Galvanizers Corporation Pty Ltd, Ref No ICP/BCMS-1/00, Australia, 2000. 47 p.

7. Catalogue: MP 200 Multiplate Assembly Time Chart. Asset International Ltd, England, 2000. 69 p.

8. http://www.csppacific.com/multiplates.htm (New Zealand, printout from 01-03-22).

9. Catalogue: Multipel trummor. Gavle Vagtrummor, Sweden, 1994. 15 p.

10. Chandler, H. M. Heavy construction cost data. $15^{\text {th }}$ Annual Edition, RSMeans Company, Inc, USA, 2000. $330 \mathrm{p}$.

11. Janusz, L. Multifactor modelling of labour consumption and cost of flexible structures assembly. $\mathrm{PhD}$ thesis, Poznan University of Technology, Poland, 2004. 162 p. (in Polish).

12. http://www.viacon.pl/indexok.html

13. Janusz, L. Labor consumption research of assembly of construction from corrugated plates with the wave $150 * 50$ and $350 * 140$. In: Proc of $4^{\text {th }}$ Conference Military Engineering: Cooperation with Civil System in Crisis Situations (Materiały z konferencji naukowo-technicznej "Inżynieria wojskowa-współdziałanie z układem pozamilitarnym w sytuacjach kryzysowych"), Wrocław, 2003, p. 175-186 (in Polish).

14. AbouRizk, S.; Knowles, P. and Hermann, U. R. Estimating labor production rates for industrial construction activities. Journal of Construction Engineering and Management, 127(6), 2001, p. 502-511.

15. Bień, J. Modelling of bridge objects in process of their maintenance (Modelowanie obiektów mostowych w procesie ich eksploatacji). Wrocław: Wrocław University of Technology Press, 2002. 348 p. (in Polish).

16. Lichtarnikov, J. M. Variant design and optimization of steel structures (Вариантное проектирование и оптимизация стальных конструкций). Moscow: Strojizdat, 1979. 319 p. (in Russian).

17. Lichtarnikov J. M.; Letnikov N. S. and Levchenkov V. N. Fundamentals of technical-economical design of building structures (Технико-экономические основы проектирования строительных конструкций). Kiev-Doneck: Visha shkola, 1980. 239 p. (in Russian).

18. Aczel, A. D. Complete business statistics. Irwin/McGrawHill Higher Education, 1996. 768 p.

19. Marszałkowicz, T. Methods of the descriptive statistics in economic and agricultural research (Metody statystyki opisowej w badaniach ekonomiczno-rolniczych). Warsaw: PWN-Polish Scientific Publishers,1980. 211 p. (in Polish).

20. Welfe A. (Ed.) Econometrics. Exercises set (Ekonometria. Zbiór zadań). Warsaw: PWE, 2003. 228 p. (in Polish).

21. Welfe, A. Econometrics. Methods and their applications (Ekonometria. Metody i ich zastosowania). Warsaw: PWE, 2003. 374 p. (in Polish). 
22. Haug, E. J.; Choi, K. K. and Komkov, V. Design sensitivity analysis of structural systems. Orlando, Florida: Academic Press Inc, 1986. 486 p.

23. Chatterjee, S. and Hadi, A. S. Sensitivity analysis in linear regression. J. Wiley \& Sons, 1988. 336 p.

24. Sobotka, A. The sensitivity of logistic decisions in the building company (Wrażliwość decyzji logistycznych w przedsiębiorstwie budowlanym). Lublin: Lublin Technical University Press, 2000. 219 p. (in Polish).

25. Lawrence, J. and Fredrickson, J. Brain maker professional for windows, neural network simulation software. Version 3.1. $1993.26 \mathrm{p}$.

26. Thiel, T. Methodical aspect of multicriteria decisions in engineering of building production (Metodyczne aspekty wielokryterialnego podejmowania decyzji w inżynierii produkcji budowlanej). PhD thesis, Poznan University of Technology, Poland, 1996. 248 p. (in Polish).

27. Zavadskas, E. K. and Kaklauskas, A. Automated multivariant design of buildings: multipurpose comprehensive evaluation and selection of the most efficient version. Aalborg: Aalborg University Centre, 1991. $65 \mathrm{p}$.

28. Zavadskas, E.; Peldschus, F. and Kaklauskas, A. Multiple criteria analysis of projects in construction. Vilnius: Technika, 1994. 226 p.

29. Zavadskas, E. K. Mehrkriterielle Entscheidungen im Bauwesen. Vilnius: Technika, 2000. 208 p. (in German).

\section{TRYS DAUGIAFAKTORIO STATYBOS PROCESU MODELIAVIMO ETAPAI}

\section{O. Kapliński, L. Janusz}

\section{Santrauka}

Straipsnyje nagrinėjamas daugiafaktoris statybos procesų modeliavimas. Pasiūlyta išplèstinė modeliavimo procedūra, susidedanti iš trijų etapų, kurių kiekvienas sudarytas iš kelių veiksmų. Etapuose naudojami ịvairūs metodai ir priemonès nuo chronometravimo iki sudaryto modelio tikrinimo. Nagrinèjamoje procedūroje taikomos daugybinè ir dalinè regresinè, koreliaciné, jautrumo analizès bei autorių pasiūlytas modelis. Be klasikinių metodų, pritaikyti ir dirbtiniai neuroniniai tinklai. Siūloma metodika parengta pagal gofruotujų plieno lakštų konstrukcijų montavimo proceso pavyzdị.

Reikšminiai žodžiai: statybos valdymas, daugiafaktoris modeliavimas, gofruotujų plieno lakštų konstrukcijų montavimas.

Oleg KAPLIŃSKI. Head of the Chair of Construction Engineering and Management at Poznan University of Technology. Member of Ukrainian Building Academy, member of Civil Engineering Committee of Polish Academy of Science, Chairman of the Section of Construction Management in this Committee. His research interests include the organisation and modelling of construction processes.

Leszek JANUSZ. Chief Executive Officer of ViaCon-Polska Ltd. PhD degree in Civil Engineering from Poznań University of Technology. His research interests include bridges, structures, production and construction of flexible corrugated steel structures (CSPS), particularly the management. 